\title{
ЗАРУБІЖНИЙ ДОСВІД
}

DOI 10.31558/2518-7953.2019.1.15

УДК 341.1-049.5(100)

О. Г. Турченко

завідувач кафедри конституційного, міжнародного і кримінального права Донецького національного університету імені Василя Стуса, канд. юрид. наук, доцент

\section{ВОЄННО-ПОЛІТИЧНА ІНТЕГРАЦІЯ КРАЇН В АРХІТЕКТУРІ СВРОПЕЙСЬКОЇ БЕЗПЕКИ У ДРУГІЙ ПОЛОВИНІ ХХ - НА ПОЧАТКУ ХХІ СТОЛІТЬ}

Ключові слова: безпека, інтеграція, воєнно-політична інтеграиія, співробітниитво, нейтралітет.

В сучасних умовах забезпечення внутрішньої та зовнішньої політики перестає бути функцією виключно національної держави, міждержавна система доповнюється певною двосистемою, в якій, як писали Б. Баді та П. Бірнбаум «логіка розвитку держави співіснує з логікою зростаючої автономізації суб' єктів» [1]. Все більш актуальною стає проблема безпеки та можливість їі реалізації через розширення взаємовигідного співробітництва, яке може стати одним з головних чинників стабільності і миру.

Необхідно відзначити, що в Європі щільність різноманітних інститутів міжнародної взаємодії з питань безпеки $є$ найвищою у світі. Всі вони покликані надати широкий діапазон засобів для вирішення загальних завдань безпеки та вироблення міжнародного комплексного підходу до врегулювання криз та проведення операцій. При цьому характерною рисою європейської безпеки продовжує залишатися високий ступінь інституціоналізації і інтеграції більшості європейських країн до НАТО. Хоча єдиного розуміння держав щодо розвитку військовооборонного співробітництва в Свропі ніколи не було. Так, наприклад, у Свропейському союзі вже досить тривалий час спостерігаються дві тенденції. Перша, яку підтримує Франція, а з середини 1990 -х років XX століття - і Німеччина, полягає в бажанні відокремитися в питаннях континентальної безпеки від США і НАТО та створити власну, європейську систему безпеки. Друга - навпаки спрямована на зміцнення позиції НАТО в Свропі, зокрема, проти спроб підірвати монополію 
НАТО на гарантування безпеки в Свропі активно виступають такі країни, як Велика Британія, Італія, Португалія, Нідерланди, Данія, а також усі члени НАТО 3 числа країн Центральної і Східної Свропи, які з 2004 року є й членами СС [2, с. 43].

Окремі аспекти становлення і розвитку європейської системи безпеки досліджувалися в роботах М. О. Баймуратова, А. З. Георгіци, В. Н. Денисова, О. А. Делінського, С. В. Кульчицького, Л. Д. Тимченка, С. В. Толстова, М. Ю. Черкеса i інших. Концептуальні засади міжнародної співпраці у сфері міжнародної безпеки вивчали також зарубіжні фахівці-міжнародники і політологи, зокрема, Е. Адлер, М. Арах, М. Барнетт, Ю. А. Борк, Р. Гарднер, Ф. Демішель, А. Джорж, К. Дойч, П. Л. Іванов, М. Крейг та ін.

В контексті цього дослідження інтерес представляють публікації Дж. Ховарта [3], М. Арах [4], присвячені історії Європейської політики в галузі безпеки і оборони (далі- СПБО) ЄС, становленню відносин СС і НАТО; дослідження «Центру європейських реформ» (Centre for European Reform), очолюваного Ч. Грантом [5], присвячені історії зовнішньої політики Євросоюзу, військово-політичній і військово-технічній іiі складовій, взаєминам НАТО і ЗСС у першій половині 1990-х років; доповідь Р. Сіннотта, що містить результати дослідження громадської думки в країнах Західної Свропи щодо політики безпеки, ролі НАТО і спільної зовнішньої політики і політики безпеки (далі - СЗППБ) СС в регіональній безпеці [6].

Разом $з$ тим залишаються недостатньо дослідженими альтернативні підходи до забезпечення національної безпеки в умовах військово-політичної інтеграції в Свропі. У зазначеному ракурсі цікавим є виявлення особливостей участі у військово-політичній інтеграції в архітектуру європейської безпеки у другій половині XX - на початку XXI століть країн, щзо реалізовували і реалізовують альтернативні підходи до забезпечення нацуінальної безпеки, щ̧о і є метою изієї статті.

Відповідно до цієї мети доцільно розглянути позицію Великою Британії та Франції, які пройшли шлях від автономної позиції до позиції «флагмана» в європейській воєнно-політичній інтеграції; країн Північної Свропи, які тримали у воєнній політиці курс на неприєднання до міжнародної блокової політики, забезпечення нейтралітету і пропонували проекти створення автономної північноєвропейської оборони, та Австрії, яка, хоча і спирається на засади нейтралітету, бере активну участь у європейській воєнно-політичній інтеграції.

Щодо Великої Британї американський дослідник Р. Розекранц відзначає, що «перші два роки після закінчення війни англійське стратегічне планування не було досить визначеним, і лише в 1948 році військова політика набула чітких контурів: «вороги були офіційно визначені, з союзниками встановлювалися безпосередні відносини, а характер і стратегія ймовірних військових компаній були приблизно сформульовані» [7, с. 68]. 
Ще 4 березня 1947 року Велика Британія і Франція з метою попередження можливості відродження німецької агресії підписали Дюнкеркський договір, який став підгрунтям в системі військово-політичних союзів, покликаних служити досягненню Великою Британією ії зовнішньополітичних цілей [8].

У березні 1948 року Англія, Франція та країни Бенілюксу підписали в Брюсселі Договір про економічне, соціальне та культурне співробітництво та колективну самооборону (Західний союз або Брюссельський пакт). У рамках цього союзу було створено спільні збройні сили.

Ернест Бевін, міністр закордонних справ Великої Британії, вважав, що без підтримки Америки будь-яка західноєвропейська система буде мати невелике значення. За його задумом військово-політичний союз західноєвропейських держав мав спиратися на американську військову та економічну міць і стати першим важливим кроком в процесі консолідації західної демократичної системи [9, c. 9-10].

Група британських високопосадовців, яка зібралася для неформального обговорення з європейського співробітництва у січні 1949 року в ході переговорів по НАТО [10], підтверджувала: «Починаючи з післявоєнного планування, наша політика полягала в тому, щоб забезпечити тісне політичне, військове та економічне співробітництво з США ... Це завжди буде мати вирішальне значення для нашої безпеки... Ми сподіваємося забезпечити особливі відносини з США і Канадою ... оскільки ми не можемо покладатися на європейські країни» [11]. Велика Британія також розглядалась Сполученими Штатами як «необхідна».

3 цієї причини ідея європейської воєнно-політичної інтеграції та активізації діяльності Західноєвропейського союзу (далі - ЗЄС) з самого початку не викликала особливого ентузіазму у Великої Британії, яка не бажала ослаблення НАТО. Британія продовжувала наполягати на тому, що зовнішня політика і політика безпеки повинні будуватися на національній основі і в підсумку підтримала і розширення функцій ЗЄС, в якому на відміну від $Є С$, співпраця здійснювалася на міждержавній основі [12, с. 374].

Але після визначення Маастрихтським договором 1993 року ЗСС основним «військовим підрядником» СС та перетворення ЄПС на СЗППБ Велика Британія була в числі держав, що наклали в 1997 році вето на пропозицію про злиття функцій ЗСС з СС, оскільки, по-перше, ключова функція ЗСС, на думку британського уряду, полягала в підтримці НАТО і, по-друге, в Лондоні вважали, що це рішення підірвало б європейські позиції Британії як держави-переможниці у Другій світовій війні, оскільки одне з провідних місць в ЗСС традиційно займала Німеччина [13, с. 110].

Ставлення Британії до європейської військово-політичної інтеграції докорінно змінилося тільки з приходом до влади в 1997 році лейбористського уряду 
Т. Блера, який спробував поєднати атлантизм з європейською обороною. Як результат, 4 грудня 1998 року Велика Британія і Франція підписали Декларацію Сен-Мало, в якій визнавалось, що Європейському союзу необхідний надійний військовий потенціал, засоби і готовність його застосувати [14, с. 8-9]. В листопаді 1999 року лідери двох країн запропонували главам держав-членів СС створити в рамках СЗПБ ЄПБО і висунули пропозицію про створення до 2003 року в рамках ЄПБО Європейських сил швидкого реагування (далі - ССШР).

Хоча знов, незважаючи на обіцянки лейбористів повернути Британію «до серця Європи», реальне ставлення Британії до військово-політичної інтеграції до ЄС виявилося досить стриманим, всередині $Є С$ навколо Британії склалася група країн, які віддавали перевагу трансатлантичним зв'язкам.

Урядом Д. Кемерона був зроблений вибір на користь двостороннього франкобританського співробітництва, яке активно розвивалося ще з 1990-х років (і навіть давало Лондону надію на заміну франко-німецької осі в СС на франко-британську). Так, у 1994 році Дж. Мейджор і Ф. Міттеран підписали угоду про створення спільного військово-повітряного командування, яке могло використовуватися в кризових ситуаціях, в 1996 році була підписана аналогічна угода про військовоморське співробітництво, всього між країнами налічувалося більше двох десятків спільних військових проектів. Не дивлячись на послаблення військового співробітництва після іракської кризи 2003 року, в листопаді 2010 року між країнами була підписана угода з двостороннього співробітництва у сфері оборони і безпеки, що мала фактично прямо протилежний характер у порівнянні з Декларацією Сен-Мало 1998 року. Угода в тому числі передбачала створення до 2016 року спільного експедиційного корпусу для проведення операцій як в рамках НАТО або ЄС, так і на двосторонній основі, створення спільної авіаносної ударної групи і розвиток ядерного співробітництва [15, с. 8-9]. В якості прикладу практичного втілення цих домовленостей можна навести операції в Лівії (2011 рік) та Малі (2013 рік), коли Британія і Франція діяли або в рамках НАТО (як в Лівії), або на двосторонній основі (як в Малі) при мінімальній участі СС, показавши в цілому високий рівень взаємодії.

Основні цілі та завдання у сфері захисту національної безпеки сформульовані у Стратегії національної безпеки Великобританії «Безпека у взаємозалежному світі» 2008 року. Показово, що у Стратегії в редакції 2010 року (зі змінами) поряд із загрозами визначені явища, які не є загрозами національній безпеці, однак за певних умов стають факторами, що породжують нестабільність і конфлікт: недостатня ефективність дії міжнародних інструментів (ООН і Ради Безпеки ООН); зміна клімату; боротьба за доступ до енергоресурсів і сировини; бідність; нерівність; глобалізація, причому ризики та виклики є взаємопов'язаними та взаємообумовленими [16]. 
В «Стратегії національної безпеки і огляді стратегічної оборони і безпеки Великобританії» 2015 року, розрахованій до 2025 року, зазначається, що Велика Британія орієнтує свою зовнішню політику на забезпечення стабілізації ситуації за кордоном, і хоча нині немає прямої військової загрози нападу на територію Великої Британії, проте «наша готовність до дій у відповідь проходить перевірку польотами військових літаків, переважно російських, поблизу британських повітряних кордонів, що почастішали останнім часом, і активізацією військово-морської діяльності поблизу територіальних вод королівства». Одночасно Лондон залишає відкритою можливість співпраці з РФ з питань глобальної безпеки, включаючи міжнародні зусилля по боротьбі з ІДІЛ і взаємодію щодо іранської ядерної програми. Сполучене Королівство має намір продовжувати виконувати свої зобов'язання в рамках НАТО, розвивати та поглиблювати відносини зі Сполученими Штатами, які «є світовим лідером в економічній і оборонній сферах і на яких світ продовжує дивитися як на гаранта глобальної стабільності, здатного очолити міжнародні дії у відповідь на кризи» [17]. Слід відзначити, що цей документ де-факто практично повністю перекреслив положення колишнього Огляду2010 [18, с. 591].

Що стосується оцінки політики національної безпеки самими британцями, то Королівський інститут об'єднаних служб (RUSI) оцінив недавні військові дії Сполученого Королівства в Афганістані, Іраку та Лівії і їх довгострокові наслідки як «стратегічні невдачі» $[19,20]$, а у доповіді RUSI 2014 року, присвяченій участі Великобританії у військових операціях з 1991 року, відзначені ті суттєві розбіжності, які найчастіше виникають між риторичною прихильністю Великої Британії міжнародним нормам і їх фактичним застосуванням [21].

Таким чином, реальне ставлення Великої Британії до військово-політичної інтеграції до ЄС виявилося досить стриманим, всередині ЄС навколо Британії склалася група країн, які віддають перевагу трансатлантичним зв'язкам, Сполучене Королівство виконує і має намір продовжувати виконувати свої зобов'язання в рамках НАТО, розвивати та поглиблювати відносини зі США.

Щодо Франиії, то, як зазначає Є. Ю. Пивоваров, „дипломатична й безпекова стратегія Франції побудована таким чином, що їй вдалося свого часу досить вдало маневрувати поміж потужних «ворогуючих таборів», не виступаючи при цьому концентруючим конфліктогенним фактором та не втручаючись у резонансні події, майстерно відстоюючи власну точку зору їх бачення «на рівновіддаленій відстані»" [22, с. 4].

Після закінчення Другої світової війни генерал Ш. де Голль намагався максимально закріпити незалежницьку та автономну позицію Франції щодо важливих подій світового життя, обравши тактику «балансування» між інтересами СРСР та США у біполярному світоустрої. Після розпаду ялтинсько-потсдамської 
системи міжнародних відносин, головними трендами розвитку системи національної безпеки цієї держави стали: збереження та еволюція голлізму, розбудова всебічного партнерства зі США, структурне реформування усього механізму забезпечення державної безпеки, оновлення методів реагування на новітні форми загроз та ризиків, якнайшвидша адаптація держави до нового геополітичного світоустрою та синхронізація обороноздатності держави з вимогами нової геополітичної епохи [22, с. 12].

У 1958 році президент Франції Шарль де Голль запропонував заснувати тристоронній директорат НАТО в складі США, Великої Британії і Франції і попросив надати Франції допомогу в створенні ядерної зброї. Отримавши відмову, французький уряд прийняв рішення про поступовий вихід Франції з військової організації НАТО, про що було остаточно оголошено на початку 1966 року. Згідно iз заявою Франції всі об’єкти Альянсу, а також об’єкти ОЗС (Об’єднаних збройних сил) НАТО на ЦЄ ТВД (Центрально-європейському театрі військових дій) мали покинути територію країни до квітня 1967 року. Після цього ядерна політика Франції стала найважливішою складовою загальнодержавної діяльності та займала найвищий рівень значущості в ієрархії стратегій національного безпекового планування країни, визначаючи систему державних пріоритетів у галузі внутрішньої та зовнішньої політики. Ядерна зброя розглядалась французькою політичною елітою не як засіб, а як «гарантуючий фактор» досягнення міці національної безпеки, при цьому виключаючи можливість їі застосування у якості превентивного військового заходу [22, с. 16].

За президентства Жака Ширака Франція провадила політику побудови європейської системи безпеки та оборони і розглядала таку систему як самостійну повноцінну військову структуру, що могло означати перетворення Свропейського союзу в альтернативну структуру для НАТО, що в свою чергу, спричинило б ослаблення впливу США в Свропі. В основу зовнішньополітичного курсу Франції президент Ніколя Саркозі не закладав політику суперництва з США і розглядав всі можливі шляхи взаємовигідного співробітництва двох країн, особливо в контексті безпеки та оборони, підкреслював важливість тісної співпраці НАТО та СС [23]. 11 березня 2009 року Ніколя Саркозі, під час конференції «Франція, європейська оборона і НАТО у ХХІ столітті» в Парижі, проголосив про відновлення участі Франції у військових структурах Альянсу Північноатлантичного договору, про що було оголошено ще під час проведення Бухарестського саміту НАТО у 2008 році та підтверджено під час Мюнхенської конференції безпеки 7 лютого 2009 року. Зобов’язання Ніколя Саркозі відновити повне членство Франції в усіх структурах НАТО зафіксовано в Білій книзі Франції з національної безпеки і оборони, прийнятій в червні 2008 року [24, с. 232]. 
На відміну від попередньої стратегії 1994 року Біла Книга-2008 визначає, що завдання держави - передбачати та попереджати виникнення загроз національній безпеці, мінімізувати вразливість нації та бути готовою до швидкої реакції на небезпечні явища глобального характеру.

Франція у новій стратегії національної безпеки робить акцент на особливій ролі ЄС у світовому політичному просторі й докладає максимум зусиль до перетворення $С С$ на найпотужнішого актора міжнародної системи безпеки з власним автономним потенціалом долати конфлікти і кризові ситуації.

«Біла книга» з оборони і національної безпеки (2013) зазначає в якості стратегічних інтересів Франції: підтримання миру на європейському континенті, в зонах, до нього прилеглих зі сходу і півдня, в середземноморському басейні й на Близькому Сході; збереження повноцінної економічної активності країни, свободи зовнішньої торгівлі та комунікацій, безпеки морських шляхів; забезпечення незалежності країни, виконання міжнародних зобов'язань, зміцнення демократії та правопорядку [25, с. 13-15].

На думку Є. Ю. Пивоварова, «питання «конфлікту ідей» між європейською та євроатлантичною моделлю для СС еволюціонувало, після обрання Н. Саркозі, до стану «взаємовикористання», а не вибору. Париж намагатиметься у короткостроковій перспективі використати налагоджені безпекові механізми НАТО (знаходячись у його керма) при паралельній посиленій розбудові європейської системи колективної безпеки, у тому числі з імовірним залученням європейських держав - нечленів НАТО та СС» [22, с. 17].

Прикладом розширеного оборонного співробітництва може слугувати рішення Франції від 11 червня 2015 року про її внесок до патрулювання повітряного простору над Францією і сусідніми країнами, прийняте після ретельної підготовки і планування, спільного та ефективного координування між французькою стороною і штаб-квартирою НАТО. Після короткого періоду часу, необхідного, щоб оновити і реалізувати необхідні оперативні і тактичні базові документи, французький повітряний простір було включено до Інтегрованої протиповітряної і протиракетної системи оборони НATO (NATO Integrated Air and Missile Defence System - NATINAMDS). Станом на 10 червня 2015 року станції НАTO з протиповітряної і протиракетної оборони є наріжним каменем колективної оборони Альянсу [26].

Основою для формування закону про військове планування на 2019-2025 роки став Стратегічний огляд 2017 року [27], поділений на три частини (стратегічний контекст; нові форми війни та конфліктів; нова стратегія безпеки Франції).

Як зазначають експерти, аналіз Стратегічного огляду дає підстави «очікувати більшого відкриття Франції до безпекової співпраці в межах ЄС та НАТО, але не варто переоцінювати його, оскільки, найімовірніше, таке відкриття обмежить- 
ся географічно найбільш близькими Франції країнами, як от Німеччина, Італія, Іспанія та Велика Британія» [28].

Крім того, Франція володіє найпотужнішим потенціалом космічних систем серед держав-членів Свропейського Союзу, при цьому хоча космічна політика країни інтегрована в пан'європейський проект, Франція завжди будувала ії незалежно і паралельно з наддержавами. Франція розглядає вільний доступ до космосу як питання національного суверенітету, яке гарантується наявністю системи ракет-носіїв [29].

Таким чином, Франція поступово відходить від незалежницької позиції у питаннях військово-політичної інтеграції, хоча їі космічна політика завжди будувалася незалежно і паралельно з наддержавами, починаючи використовувати налагоджені безпекові механізми НАТО (знаходячись у його керма) при паралельній посиленій розбудові європейської системи колективної безпеки, у тому числі з імовірним залученням європейських держав - нечленів НАТО та ЄС.

Після включення Північно-Льодовитого океану з прилеглими територіями європейської Півночі до «зони безпеки» в рамках Договору про оборону Західної півкулі між США та країнами Латинської Америки, підписаного у вересні 1947 р. у Ріо-де-Жанейро, особливо посилилося стратегічне значення Скандинавських країн.

Країни Північної Європи у воєнній політиці тримали курс на неприєднання до міжнародної блокової політики, забезпечення нейтралітету, відповідно пропонували проекти створення автономної північноєвропейської оборони, але при цьому завжди орієнтувалися на Велику Британію та США. Так, наприклад, Норвегія після Другої світової війни у своїй зовнішньополітичній концепції демонструвала послідовну атлантичну орієнтацію, хоча не відмовлялась від збереження нейтралітету. В «Основних напрямах зовнішньої політики Норвегії» передбачено, що «Норвегія прагнутиме досягнення обов’язкових спеціальних воєнних угод з питань оборони Північної Атлантики ... Норвезький уряд із задоволенням поставився б до приєднання Данії, Нідерландів, Бельгії і Франції до цієї системи» [30].

У політичній програмі розвитку країни 1945 року підкреслювалося, що оборона держави повинна розбудовуватися з урахуванням воєнного досвіду, а іiі метою має бути як захист Норвегії, так і виконання міжнародних повоєнних зобов'язань [31, с. 246]. В свою чергу, міністр закордонних справ країни Г. Ланге у лютому 1946 року наголошував, що необхідно «робити все у якості лояльного члена Об'єднаних Націй, для укріплення взаємної довіри між країнами ... співробітничати з усіма, не беручи участі у створенні будь-яких блоків» [32, с. 131].

Данія також у значній мірі покладалась на ООН як гаранта національної безпеки і спиралася у своїй політиці на провідні атлантичні держави, але політика нейтралітету була пріоритетною у сфері безпеки країни [33, с. 261]. 
Швеція ж ще після закінчення війни з Норвегією у 1814 році у сфері безпеки дотримувалась курсу на нейтралітет під час збройних конфліктів і неучасть у військових блоках у мирний час [34, с. 49], хоча нейтралітет ніколи не закріплювався документально і проголошувався урядом у кожному окремому випадку [35, c. 43].

Загалом, можна виділити два характерних підходи до питань безпеки серед скандинавських країн. Представники одного напряму (Норвегія) розглядали «скандинавську оборону з позицій створення стабільного нейтрального регіону в умовах «холодної війни», орієнтовану на західні сили, відповідно, США та Велика Британія мають забезпечити певну союзницьку допомогу гарантії безпеки.

Міністр закордонних справ Норвегії Г. Ланге 8 березня 1948 року заявив американським і британським послам в Осло, що він отримав попереднє повідомлення про те, що СРСР має намір вимагати, аби Норвегія підписала пакт про оборону аналогічний тому, що підписала Фінляндія. У повідомленні вказувалося, що Норвегія хоче відмовитися, але уряду необхідно знати, що, якщо раптом щось станеться, США і Велика Британія готові прийти на допомогу [36]. У результаті цього 17 березня 1948 року був підписаний Брюссельський пакт [37].

Представники іншого напряму (Данія, Швеція) вважали, що Північній Свропі потрібна була незалежна від США оборона та безкомпромісний нейтральний статус. Відповідно, 10 травня 1948 року Швеція виступила з ініціативою проведення переговорів зі створення нейтрального Скандинавського оборонного союзу, який би мав функціонувати протягом десяти років. Цей союз передбачав розробку спільного зовнішньо політичного курсу, координацію процесу переозброєння, невтручання у будь-які збройні конфлікти, що велися на територіях інших країн.

Г. Ланге також запропонував підготувати спільну оборонну угоду між країнами Скандинавії [38, с. 94-95] з орієнтацією на захід, щоб мати певні гарантії в питаннях отримання американського озброєння та допомоги у випадку війни. Таке бачення Скандинавського оборонного союзу підтримували і США та Велика Британія. В результаті 19 лютого 1949 року на спеціальному засіданні Норвезької робітничої партії, на яку було запрошено колег по переговорному процесу з питання створення Скандинавського оборонного союзу з Данії та Швеції, міністр закордонних справ Норвегії Г. Ланге наголосив на пріоритетності атлантичного (НАТО) варіанту в інтересах безпеки Осло [39, с. 509], відповідно ідея створення союзу припинила своє існування.

І вже 24 лютого 1949 р. міністр закордонних справ Норвегії заявив, що уряд країни прийняв рішення увійти у заплановане співробітництво демократичних народів з організації безпеки, тобто вступити до НАТО. Згодом аналогічне рішення прийняла Данія.

Таким чином, після вступу 4 квітня 1949 року Данії та Норвегії до НАТО країни переорієнтували свою політику безпеки, спрямованість якої почала ви- 
значатися двома векторами. Щодо СРСР застосовувався ефект «стримування», а щодо самого альянсу - інтеграція, яка розглядалася в якості необхідної умови для отримання допомоги союзників, хоча в рамках Атлантичного альянсу країни зайняли особливу позицію, спрямовану на дотримання безпеки у північноєвропейському регіоні.

Швеція залишилася на позиціях неприєднання, грунтуючи співпрацю з НАТО на політиці військового неприєднання та сталої національної згоди, і акцентуючи увагу на сферах, які відповідають спільним цілям. Першим значним кроком у бік Альянсу стало іï приєднання у 1994 році до програми НАТО «Партнерство заради миру», однак після агресії США і учасників Північноатлантичного договору в Лівії громадськість не підтримала ініціативу вступу до НАТО. 31997 року Швеція є членом Ради євроатлантичного партнерства. Швеція регулярно бере участь у військових навчаннях Альянсу: надавала контингенти «миротворчих сил» в Боснії та Герцеговині (1995 рік) і Косово (1999 рік) під егідою НАТО.

Шведський персонал працював разом з союзними військами в рамках Міжнародних сил сприяння безпеці в Афганістані з 2003 року до завершення місії МССБ в 2014 році. Вона надала спеціальну техніку та матеріально-технічну підтримку, очоливши багатонаціональну команду з відбудови провінцій в МазаріШаріф в 2006 році. Швеція нині надає підтримку в наступній місії («рішуча підтримка») щодо подальшого навчання, консультування та надання сприяння афганським силам безпеки. Швеція також надала понад \$ 11 млн для національної армії Афганістану. 3 квітня 2011 року Швеція брала участь у військовій операції «Юніфайд протектор» в Лівії в рамках резолюцій 1970 і 1973 Ради Безпеки ООН.

Швеція вносить свій внесок в розвиток концепції Бойової групи ЄС. Вона співпрацює з Естонією, Фінляндією і Норвегією, в числі інших країн, у розвитку багатонаціональних сил швидкого реагування ЄС з підтримки миру. У періоди, поки шведської сили будуть знаходитися не в черговому режимі, для потреб ЄС, вони будуть доступні для операцій, що проводяться під керівництвом ООН i HATO. Країна також вступила до Тимчасового рішення щодо стратегічних авіаперевезень (SALIS) в березні 2006 року, а також бере участь в ініціативі Стратегічної здатності повітряних перевезень (Strategic Airlift Capability - SAC), призначеній для задоволення потреб в стратегічних перевезеннях країн-членів SAC для власних операцій, а також для місій НАТО, ООН, СС та інших міжнародних операцій [40].

Для сприяння регіональній та міжнародній безпеці спільно з країнами-членами НАТО Данією, Ісландією, Норвегією та Фінляндією країна нарощує військову співпрацю в рамках створеного в 2009 році Північного оборонного співробітництва NORDEFCO. Щодо Швеції, ця діяльність здійснюється поряд зі скандинавською бойовою групою (the Nordic Battlegroup) і співпрацею з країнами регіону Балтійського моря і Північної Європи. 
У 2009 році парламент Швеції одностайно прийняв заяву про солідарність, яка з тих пір стала частиною доктрини безпеки країни. У заяві, зокрема, сказано: «Швеція не перебуває в одному військовому союзі. Оптимальний спосіб уникнути загроз миру і нашій безпеці - діяти спільно і співпрацювати з іншими країнами. Неможливо уявити собі військові конфлікти в нашому регіоні, які торкнулися б лише однієї країни. Швеція не буде залишатися пасивною, якщо якась державачлен $Є С$ або північноєвропейська країна постраждає від лиха або піддасться нападу. Ми очікуємо, що ці країни діятимуть аналогічним чином, якщо постраждає Швеція. I тому Швеція повинна бути здатна надавати військову підтримку і отримувати ऑï» [41].

Після саміту НАТО в Уельсі в 2014 році Швеція отримала статус партнера 3 розширеними можливостями, що надало платформу для розвитку більш гнучких і індивідуальних відносин, крім інших форматів партнерства і, відповідно, співпало з прийняттям закону Швеції про оборону на період з 2016 по 2020 роки, спрямованого на підвищення боєздатності збройних сил, відродження підходу до забезпечення безпеки за участю всього уряду, зміцнення стійкості відповідно до семи базових вимог, прийнятих НАТО на зустрічі на вищому рівні в Варшаві.

У 2016 році в Швеції прийнятий закон про «Меморандум про взаєморозуміння щодо підтримки приймаючої країни». Мета цього меморандуму з НАТО зробити так, щоб Швеція як приймаюча країна могла надавати ефективну підтримку військовим заходам на території Швеції в зв'язку з навчаннями, кризами або військовими операціями в Швеції і в прилеглому районі [41]. У 2016 році країна також підписала з Естонією, яка $є$ членом НАТО, та з Фінляндією угоду про військову взаємодопомогу.

В зв'язку зі вступом до НАТО Данії та Норвегії у досить складному становищі опинилася Фінляндія, внаслідок зобов'язань перед СРСР по Договору 1948 року. Фінляндія була зацікавлена у Скандинавському нейтральному Союзі, висунувши себе на роль посередника між СРСР та Скандинавськими країнами у питанні мирного врегулювання. Але в умовах перебування радянських збройних сил на території Фінляндії ідея створення і функціонування нейтрального оборонного союзу між країнами півночі Свропи була практично нездійсненною.

Відносини між Фінляндією та іншими міжнародними безпековими організаціями будуються аналогічно «шведським». У нинішніх умовах безпеки, що характеризуються підвищеною стурбованістю з приводу російської військової діяльності, НАТО нарощує співпрацю з Фінляндією. Фінляндія, аналогічно Швеції, поряд з Австралією, Грузією та Йорданією, має статус партнера з розширеними можливостями, що означає розширення політичного діалогу, в тому числі на найвищому рівні, обмін інформацією про гібридні війни, координацію підготовки та навчань, а також підвищення загальної поінформованості про ситуацію для усу- 
нення загальних загроз та вироблення спільних дій, якщо це необхідно. Країна також бере участь в укріпленні Сил реагування HATO (NRF) з урахуванням національних рішень, а також проводить регулярні консультації з НАТО з безпеки в Балтійському регіоні.

У 2017 році Фінляндія створила Гельсінський Європейський центр передового досвіду з протидії гібридним загрозам, який підтримується НАТО і СС [42].

Складне ставлення країн і до ядерної зброї. Норвегія та Данія ніколи не відмовлялись від прийнятої Північноатлантичним альянсом доктрини про застосування ядерної зброї, як «останнього засобу», країни брали участь у створенні системи зв'язку для ядерних сил НАТО [43, с. 178-179]. Але у 1960-1961 роках Данія і Норвегія прийняли остаточне рішення про неможливість розташування ядерної зброї на їх територіях, хоча у 1963 році вони відкинули пропозицію Фінляндії створити скандинавську без'ядерну зону, посилаючись на те, що оборона скандинавських країн (Данії та Норвегіï) містить у своїй основі концепцію ядерного стримування, як стратегічного фундаменту західного військового союзу. Аналогічну позицію зайняла і Швеція [44, с. 326].

Таким чином, можна погодитися з В. Павленко, що після Другої світової війни держави Північного регіону обрали різні підходи до вирішення питання національної безпеки. Політика нейтралітету, якої дотримувалися країни напередодні Другої світової війни, поступилася місцем курсу на членство у НАТО.

Після звільнення Австрії збройними силами СРСР в березні-травні 1945 року їі територія була розділена на чотири окупаційні зони. Французька зона охоплювала федеральні зони Форарльберга і Тиролю (без східного Тиролю). Каринтія, Штирія та східний Тироль відійшли до британської зони; Зальцбург, Верхня Австрія на південь від Дунаю - до американської. До радянської зони - верхньоавстрійський район Мюльфіртель, Нижня Австрія і Бургенлянд. Крім того, ці чотири держави зайняли по одному сектору Відня.

У таких умовах саме ідея постійного нейтралітету могла б стати відправною точкою для компромісу між усіма зацікавленими сторонами та забезпечити відновлення суверенітету країни та швидке припинення окупаційного режиму.

У березні 1955 року федеральний уряд Австрії заявив, що країна не має намірів вступу до військових союзів, коаліцій, не має наміру розміщувати на своїй території військові бази. I вже 15 травня 1955 року у віденському палаці Бельведері міністри закордонних справ СРСР - В. Молотов, Великої Британії - Г. МакМіллан, Франції - А. Піне, США - Д. Дюлле та канцлер Австрії - Л. Фігель підписали Договір про відновлення незалежної демократичної Австрійської республіки.

7 червня 1955 року урядові партії Австрії запропонували Національній раді проект резолюції, що містила положення про нейтралітет, визнання його державами, які його підписали, та членство в ООН. 8 червня 1955 року ця резолюція 
була прийнята Національною радою Австрії, яка офіційно проголосила статус постійного нейтралітету. 19 липня 1955 року законопроект був схвалений парламентом і Національна рада його ратифікувала. 26 жовтня 1955 року Національна рада прийняла Федеральний конституційний закон «Про нейтралітет» [45]. 14 листопада 1955 року Австрія звернулася до усіх 65-ти країн, з якими вона на той момент підтримувала дипломатичні відносини, з проханням визнати цей закон як основу австрійської зовнішньої політики.

Обов'язок збереження та захисту постійного нейтралітету Австрії, як одне із завдань національної оборони, містився у п. 1 ст. 9а Федеральної конституції.

Саме в цих умовах склалася формула «ані Захід, ані Схід», що на думку В. Блази свідчить про прагнення Австрії, яка знаходилася на межі двох зон впливу, до самоусунення від певних міжнародно-політичних процесів [46, с. 2]. Модель постійного нейтралітету розглядалася в низці меморандумів та урядових заяв [47, с. 242-254], в яких підкреслювалося зобов'язання країни не брати участь у будь-яких війнах у майбутньому, нейтралітет за мирних часів.

Австрійське суспільство розуміло постійний нейтралітет як міжнародно-правовий статус держави. Відповідно нейтралітет представляв собою певну «ізоляцію» від зовнішнього світу у відповідних, зокрема, військових і дотичних до них сферах. Згідно із загальноприйнятим підходом, який поділяла більшість вчених та експертів Австрії у сфері міжнародного права, постійно нейтральна держава, 3 одного боку, володіла усіма правами і обов'язками, що випливали із звичайного нейтралітету, а з іншого, повинна виконувати зобов'язання, які були результатом постійного характеру даного статусу [48, с. 202-203].

Цікавою є точка зору політолога Антона Пелінкі щодо австрійського «обмеженого» або «залишкового нейтралітету». Він вважає, що це свого роду «вигадка»: доки європейська спільна зовнішня політика і політика безпеки буде залишатися слаборозвиненою, Австрія зможе жити 3 цією «вигадкою» [49, с. 151].

Треба зазначити, що для забезпечення можливості участі в складі $€ С$ нейтральних та позаблокових країн СС змінило власне законодавство. Такі країни отримали можливість брати повномасштабну участь в економічних союзах (ЄС) та в системі загальноєвропейської безпеки (ОБСЄ). Проте такий статус виявився несумісним з членством в НАТО через принцип колективної оборони. Нейтральні та позаблокові країни змогли брати участь у миротворчих операціях під егідою міжнародних організацій (ООН, ОБСЄ) на рівні гуманітарної, санітарної, технічної допомоги, а позаблокові держави - на рівні військової допомоги [50, c. 5]. Так, 24 липня 1994 року було підписано Угоду про приєднання Австрії до ЄС і з 1 січня 1995 року Австрійська Республіка приєдналася до Європейського Союзу, відповідно, були прийняті положення про «Загальну зовнішню політику 
та політику безпеки», а після Лісабонської угоди 2007 року Австрія прийняла пункти «Свропейської безпеки і політики оборони» [51].

Як відмічається в літературі, після приєднання до ЄС Австрійська Республіка втратила свій міжнародний посередницький статус часів «холодної війни», що дало можливість говорити про кінець «австрійської винятковості» [52, с. 16], і ставши частиною поглиблених європейських політичних, військових та економічних інтеграційних процесів, Австрія так повністю і не узгодила свою політику безпеки 3 «атлантичним співтовариством» [53, с. 95]. Так, не приєднавшись до НАТО, під час війни в Перській затоці (1991 рік) і Операції проти Сербії (1999 рік) Австрія відкрила свій повітряний простір для авіації НАТО. Крім цього, вона бере участь в програмі НАТО Партнерство заради миру і їі війська брали участь в місії миротворців в Боснії та Герцеговині.

Таким чином, Австрія, не дивлячись на наявність статусу нейтральної держави, приєдналася до ЄС і стала частиною поглиблених європейських політичних, військових та економічних інтеграційних процесів.

3 вище наведеного можна зробити такі загальні висновки:

У другій половині XX-на початку XXI століть Велика Британія демонструє спадкоємність в політиці національної безпеки в плані відповіді на основні загрози, будує свою безпеку на традиційних принц̧ипах атлантизму, має міияну позицію в НАТО, співпраџює і має намір продовжувати співпрацювати з союзниками по НАТО, європейськими краӥнами-сусідами і структурами СС, щуо має внести внесок в забезпечення безпеки і стабільності на європейському континенті. Велика Британія є краӥною, без якої подальша європейська інтеграчуія в галузі оборони буде малопродуктивною.

Франція також змінила незалежницьку та автономну позицію, тактику «балансування» між інтересами СРСР та США у біполярному світоустрої на використання налагоджених безпекових механізмів НАТО при паралельній посиленій розбудові європейської системи колективної безпеки, у тому числі з імовірним залученням європейських держав - нечленів НАТО та СС.

Політика нейтралітету, якої дотримувалися Данія та Норвегія напередодні Другої світової війни, поступилася місием курсу на членство у НАТО.

Фінляндія залишається на позиціях нейтралітету. Швеція намагається послідовно дотримуватись політики неприєднання. Фінляндія та Австрія репрезентують свій нейтралітет відносно вільно, тоді як Швеція дотримується суворіиих прини̧ипів нейтралітету.

1. Гаджиев К. С. Введение в геополитику: Учебник. Москва: Логос, 2000. 257 с. URL: http://uchebnik-online.com/soderzhanie/textbook_195.html 
2. Бычковская О. Взаимоотношения ЕС и НАТО в контексте евроатлантической безопасности. Журнал международного права и международных отношений. 2011. № 1. С. 43-49.

3. Howorth J. Security and Defence Policy in the European Union. Basingstoke, 2007. 315 p.

4. Arah M. Evropska Unija: Vizija politićnega združevanja. Ljubljana: Arah Consulting, 1995. $431 \mathrm{p}$.

5. Grant C. Strength in numbers Europe's foreign and defence policy. London: Centre for European Reform, Report, 06 September 1996. 59 p.

6. Sinnott R. European public opinion and security policy. Paris: Institute for Security Studies, July 1997. 37 p.

7. Henderson N. Birth of NATO. L.: Westview Press, 1983. 288 p.

8. Traité d'alliance et d'assistance mutuelle entre la France et le Royaume-Uni (Dunkerque, 4 mars 1947). URL: https://www.cvce.eu/education/unit-content/-/unit/026961fe-0d57-4314-a40a-a4 ac066a1801/5d5a64ab-9c7c-4e19-b528-9e53f9ce937b/Resources\#1fb9f4b5-64e2-4337-bc78-db7e 1978de09

9. Foreign Relations of the United States. Diplomatic Papers. Volume III, 1948. Washington: Gov. print. office. 1165 p.

10. Public Record Office (Great Britain, Kew, London). Statement on Defence 1949. Memorandum. CAB 129/32/21 CP (49) 21. URL: http://discovery.nationalarchives.gov.uk/SearchUI/ Details?uri=D7655606

11. Public Record Office (Great Britain, Kew, London). Permanent Under Secretary's Committee: briefs on foreign policy. Code 500, file 3 (papers 4510-5016) FO 371/76385.

12. Великобритания. Эпоха реформ / под. ред. Ал. А. Громыко. М.: Весь мир, 2007. 536 с.

13. Шихов Д. В. Великобритания в системе европейской безопасности: новые возможности или путь в никуда? Вестник МГИМО. 2015. № 2. С. 109-114. URL: https://cyberleninka.ru/ article/v/velikobritaniya-v-sisteme-evropeyskoy-bezopasnosti-novye-vozmozhnosti-ili-put-v-nikuda

14. British-French summit, St. Malo, 3-4 December 1998. Joint declaration on European defence. From St. Malo to Nice. European defence: core documents. Complied by M. Rutten. Paris: Institute for Security Studies Western European Union, 2001. 239 p.

15. Taylor Claire. Franco-British Defence Cooperation. Standard note SN/IA/5750. House of Commons Library. L.: 2010. 17 p. URL: http://www.parliament.uk/business/publications/research/ briefing-papers/SN05750/francobritish-defence-cooperation (дата звернення 25.07.2019р.).

16. A Strong Britain in an Age of Uncertainty: The National Security Strategy. URL: https://www.gov.uk/government/uploads/system/uploads/attachment_data/file/61936/national-security-strategy.pdf (дата звернення 25.07.2019 р.).

17. Маринин А. Стратегия национальной безопасности и обзор стратегической обороны и безопасности Великобритании (2016). Fact Military. URL: http://factmil.com/publ/strana/ velikobritanija/strategija_nacionalnoj_bezopasnosti_i_obzor_strategicheskoj_oborony_i_bezopasnos ti_velikobritanii_2016/9-1-0-988 (дата звернення 25.07.2019 р.).

18. Климова А. С. Обеспечение британской национальной безопасности от Д. Кэмерона к Т. Мэй: стратегии и реалии. Вестник РУДН. Серия: Политология. 2018. Vol. 20. № 4. C. 578-594. URL: journals.rudn.ru/political-science/article/download/20401/16571

19. Britain's Invasion of Iraq Was a Mistake and Violation of UN Principles. 06.07.2016. URL: https://www.gov.uk/government/collections/terrorism-prevention-and-investigationmeasures-act (дата звернення 14.04.2018 р.).

20. Kanter J. Intelligence Expert: Theresa May is as Big a Threat to Britain's National Security as Jeremy Corbyn // Business Insider. 17.05.2017. URL: http://uk.businessinsider.com/ anthonyglees-theresa-may-big-a-threat-to-britain-national-security-as-jeremy-corbyn-2017-5 (дата звернення 20.05.2018 p.).

21. Wars in Peace. British Military Operations Since 1991. RUSI. 2014. URL: https://rusi.org/ sites/default/files/wars_in_peace_foreword_and_intro.pdf (дата звернення 12.05.2018р.).

22. Пивоваров С. Ю. Модель національної безпеки і оборони Франції: можливості ії адаптації до умов України: Автореферат дис ... канд. політ. наук / Спеціальність 21.01.01 - основи 
національної безпеки держави (політичні науки). К.: Національний інститут проблем міжнародної безпеки при Раді національної безпеки і оборони України, 2010. 24 с.

23. Valasek T. France, NATO and European defence. URL: http://www.cer.org.uk/pdf/policybrief_eu_nato_26march08.pdf

24. Авраменко В. В. Євроатлантична політика Франції в контексті європейської доктрини безпеки та оборони. Актуальні проблеми міжнародних відносин. 2011. Випуск 102 (Частина 1). С. 229-234.

25. Livre blanc sur la défense et la sécurité nationale (2013) / Direction de l'information légale et administrative, réalisée par le Ministère de la Défense. Paris, 2013. 159 p. URL: file:///C:/ Users/User/Downloads/Livre-blanc-sur-la-Defense-et-la-Securite-nationale\%202013.pdf

26. Франция становится частью NATINAMDS. URL: http://vsenato.ru/franciya-stalachastyu-natinamds/ (дата звернення 25.07.2019 p.).

27. Revue stratégique: une analyse lucide et volontariste pour préparer la prochaine loi de programmation militaire. 04/12/2017 - Direction: DGRIS. URL: https://www.defense.gouv.fr/dgris/ presentation/evenements-archives/revue-strategique-de-defense-et-de-securite-nationale-2017 (дата звернення 25.07.2019 р.).

28. Колесник Д. Париж переосмислює загрози: як зміниться безпекова політика Франції. Європейська правда. 28 листопада 2017 року. URL: https:/www.eurointegration.com.ua/articles/ 2017/11/28/7074291/ (дата звернення 25.07.2019 р.).

29. Борзенко Д. Відповідь на російську диверсію: як Франція змінює підходи до загроз із космосу. Свропейська правда. 5 серпня 2019 року. URL: https://www.eurointegration.com.ua/ articles/2019/08/5/7099289/ (дата звернення 25.07.2019 р.).

30. Советско-норвежские отношения, 1917-1955: сб. док. / Ин-т всеобщ. истории РАН [и др.]; [редкол.: А. О. Чубарьян и др.]. Москва: ЭЛИА-АРТ-О, 1997. 681 с.

31. Ристе У. История внешней политики Норвегии. Москва: Весь Мир; [ОАО Тип. «Новости»], 2003. $413 \mathrm{c.}$.

32. Skodvin M. Norwegian neutrality and the question of credibility. Scandinavian journal of history. 1977. Vol. 2. № 1/4. P. 123-145.

33. Lammers K. C. Denmark's Relations with Germany since 1945. Denmark's policy towards Europe after 1945: history, theory and options [eds.: Hans Branner, Morten Kelstrup]. Odense, 2000. P. 260-281.

34. Johnsson H.-I. Sverige i fokus. Stockholm: Svenska institutet, 1996. $240 \mathrm{~s}$.

35. Павленко В. Воєнно-політична інтеграція країн Скандинавії в архітектурі європейської безпеки після Другої світової війни. Свропейські історичні студії. 2017. № 8. С. 39-52. URL: http://eustudies.history.knu.ua/nomer-8/ (дата звернення 25.07.2019 p.).

36. Public Record Office (Great Britain, Kew, London). Fortnightly Economic Report. Memorandum. CAB 129/25/7 CP (48) 67. URL: http://discovery.nationalarchives.gov.uk/SearchUI/Details?uri=D7655343

37. Public Record Office (Great Britain, Kew, London). The Anglo-Norwegian Fishery Dispute. Memorandum. CAB 129/30/27 CP (48) 257. URL: http://discovery.nationalarchives.gov.uk/ SearchUI/Details?uri=D7655533

38. Lange C. Political unifica tion and the Nordic Council. Cooperation and Conflict. 1965. Vol. 1. No 2. P. 94-95.

39. Einhorn E. S. The Reluctant Ally: Danish Security Policy, 1945-49. Journal of Contemporary History. 1975. Vol. 10. № 3. P. 493-512.

40. Отношения Швеции и НАТО. По материалам: http://www.nato.int/cps/en/natohq/ topics_52535.htm?selectedLocale=en\#. URL: http://vsenato.ru/otnosheniya-shvecii-i-nato/ (дата звернення 25.07.2019 р.).

41. Малмквист X. Швеция и НАTO: 23 года спустя. Вестник НАTO. 11.01.2018. URL: https://www.nato.int/docu/review/2018/Also-in-2018/sweden-and-nato-23-years-down-the-road-defence-security/RU/index.htm (дата звернення 25.07.2019 p.). 
42. Отношения Финляндии и НАТО. По материалам: https://www.nato.int/cps/en/natohq/ topics_49594.htm?selectedLocale=en\#. URL: http://vsenato.ru/otnosheniya-finlyandii-i-nato/ (дата звернення 25.07.2019 р.).

43. Berdal M. The United States, Norway and the Cold War, 1954-1960/ M. Berdal; [foreword by Olav Riste]. New York; London : St. Martin's Press ; Macmillan, 1996. XIX, 268 p.: maps. - (St. Antony's series).

44. Юссіла О. Від Великого Князівства до сучасної держави : політична історія Фінляндії від 1809 року / О. Юссіла [та ін.]; [/пер. $з$ фін. М. Гаутала, В. Пилипенко ; ред. пер. Т. та К. Тищенко]. Київ: Унісерв, 2002. 407 с.

45. Bundesverfassungsgesetz über die Neutralität Österreichs vom 26. Oktober 1955. Bundesgesetzblatt. 1955. No 211. 1 s.

46. Blasi W. Die Entwicklung der Österreichischen Neutralität in den Jahren 1945 bis 1955 unter Berücksichtigung der Haltung der SPÖ und ÖVP. Wien.: Interne Information zur Sicherheitspolitik, 2001. № 12. S. 2-10.

47. Memorandum über die Ergebnisse der Besprechung zwischen der Regierungsdelegation der Republik Österreich und der Regierungsdelegation der Sowjetunion 15. April 1955. Österreich im 20. Jahrhundert: in 2 Bänden / R. Steiniger, M. Gehler (Hrsg.). Wien.: Böhlau-Studien-Bücher, 1997. Band 2: Vom Weltkrieg bis zur Gegenwart. S. 242-254.

48. Папенко Н., Папенко С. Політика Австрійської республіки щодо статусу постійного нейтралітету (1945-1955рр.). Європейські історичні студї. 2016. № 4. C. 192-208. URL: http://eustudies.history.knu.ua/nataliya-papenko-yevgen-papenko-polityka-avstrijskoyi-respublikyshhodo-statusu-postijnogo-nejtralitetu-1945-1955-rr/

49. Pelinka A. Nach der Windstille: Eine politische Autobiografie. Wien, Braumüller Lesethek, 2009. $240 \mathrm{~S}$.

50. Вдовенко В. М. Політика нейтралітету і позаблоковості в сучасній архітектурі європейської безпеки: автореф. дис. ... канд. політ. наук: 23.00.04. К.: Київ. нац. ун-т ім. Т. Шевченка, 2006. $22 \mathrm{c.}$

51. ESDP and Austria: Security policy between engagement and neutrality / Gunther Hauser. New Brunswick (N.J.), London: Transaction Pb., 2006. P. 207-245.

52. Bischof G. Of Dwarfs and Giants: From Cold War Mediator to Bad Boy of Europe-Austria and the U.S. in the Transatlantic Arena (1990-2013). Austria's International Position after the End of the Cold War. Contemporary Austrian studies. 2013. Vol. 22. P. 13-52.

53. Сафар'янс Є. Австрія у складі Європейського Союзу. Європейські історичні студіі. 2015. № 2. C. 92-102. URL: http://eustudies.history.knu.ua/yevgenij-safar-yans-avstriya-u-skladiyevropejskogo-soyuzu/ (дата звернення 25.07.2019 р.). 